\title{
Endophytic ability of indigenous Bacillus thuringiensis strain VKK-BB2: new horizons for the development of novel insect pest-resistant crops
}

\author{
Sunitha Pola ${ }^{1}$, Amit Kumar Kesharwani ${ }^{2}$, Jyoti Singh ${ }^{1}$, Dinesh Singh ${ }^{2}$ and Vinay K. Kalia ${ }^{1 *}$ (])
}

\begin{abstract}
Background: Brinjal shoot and fruit borer (BSFB), Leucinodes orbonalis Guenee is the key pest of brinjal that causes a significant yield loss. Farmers spray wide range of insecticides right from vegetative stage till last harvesting stage to protect the crop from the notorious BSFB, which leads to pesticide residue and insecticide resistance problems. To overcome this, now focus has shifted to bio pesticides but their commercial application is limited due to their susceptibility to abiotic factors. To overcome these bottlenecks, a hidden ecological role played by entomopathogenic bacteria as endophytes was sought. The control of pests by establishment of potential entomopathogenic bacteria as an endophyte is an alternative method of pest management that may contribute to reduce or eliminate the use of pesticides.
\end{abstract}

Results: Present study describes the colonization of green fluorescent protein (GFP)-tagged potential native Bacillus thuringiensis strain VKK-BB2 (BtVKK-BB2) in brinjal plants. Seeds and seedlings of brinjal were inoculated with gfp-tagged BtVKK-BB2 cells through seed treatment, soil drenching and foliar spray. After inoculation gfp-tagged bacterium could be re-isolated from all parts of the plant. Presence of bacteria within the leaves was confirmed by amplification of $g f p$ and cry gene in the re-isolated Bt colonies from brinjal leaves and shoot. Leaves taken from the BtVKK-BB2 colonized plants were able to cause mortality when fed to neonates of Leucinodes orbonalis.

Conclusions: Establishment of native Bt strain as endophytes in plants, accompanied by the production of Cry proteins opens new horizons for the development of a novel pest-resistant crops which could be an alternative to Bt transgenic crops. However, inoculation of Bt through seed and foliar spray has to be further explored against larval herbivores especially internal borers to enhance its biocontrol potential through endophytic mediation which may open a novel set of strategies to control the insect pests in a sustainable way.

Keywords: Bacillus thuringiensis, Bioassay, Cry toxin, Endophyte, Green fluorescent protein, Plant colonization

\footnotetext{
*Correspondence: vkalia@iari.res.in; vkalia_1998@yahoo.com

${ }^{1}$ Division of Entomology, ICAR-Indian Agricultural Research Institute, New

Delhi 110012 , India

Full list of author information is available at the end of the article
}

(c) The Author(s) 2022. Open Access This article is licensed under a Creative Commons Attribution 40 International License, which permits use, sharing, adaptation, distribution and reproduction in any medium or format, as long as you give appropriate credit to the original author(s) and the source, provide a link to the Creative Commons licence, and indicate if changes were made. The images or other third party material in this article are included in the article's Creative Commons licence, unless indicated otherwise in a credit line to the material. If material is not included in the article's Creative Commons licence and your intended use is not permitted by statutory regulation or exceeds the permitted use, you will need to obtain permission directly from the copyright holder. To view a copy of this licence, visit http://creativecommons.org/licenses/by/4.0/. 


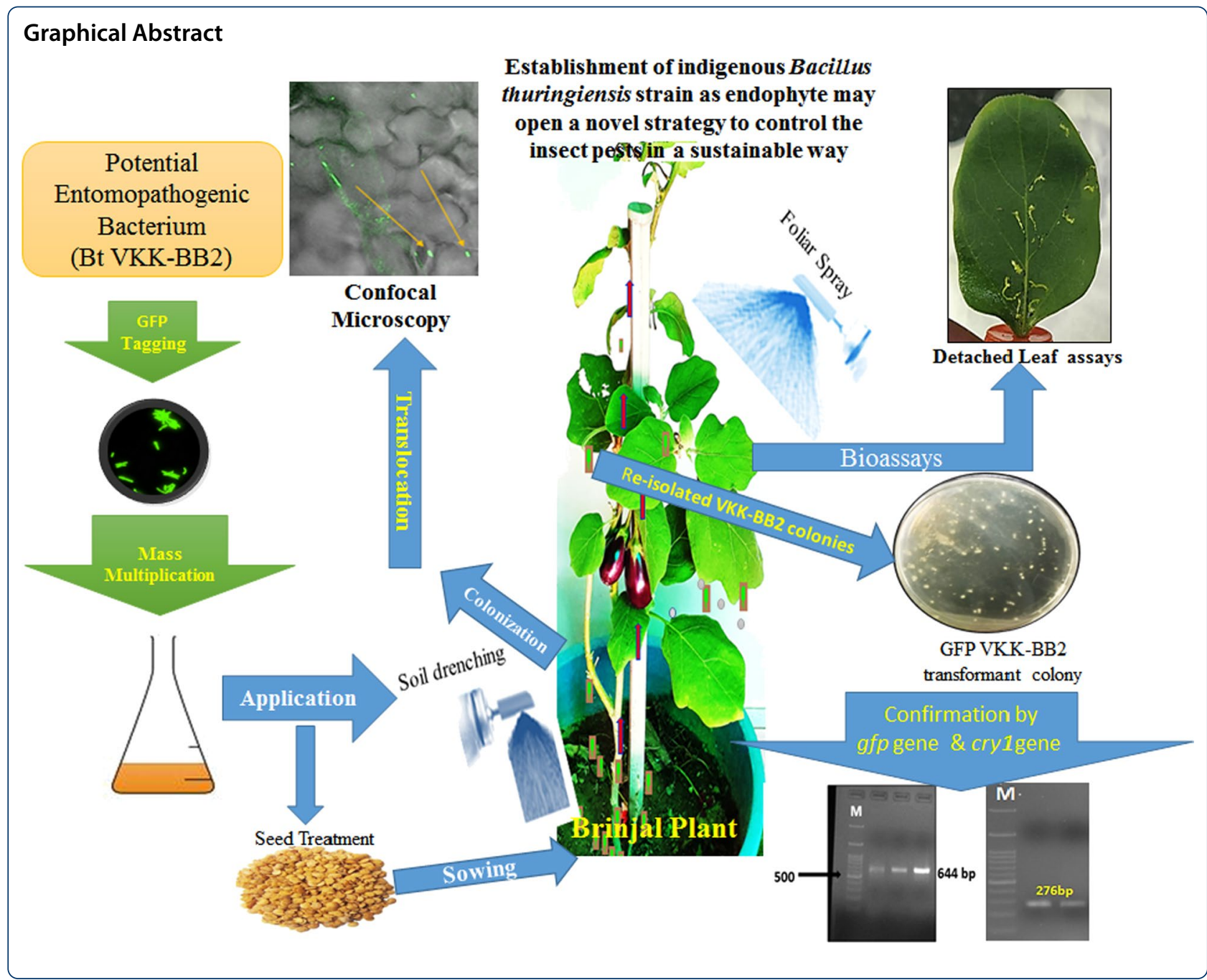

\section{Background}

Brinjal (Solanum melongena L.), also known as eggplant, is an important vegetable crop grown in India and many other parts of the world. It is tasty and nutritious vegetable rich in minerals (Choudhary and Gaur 2009). India is the second leading producer of brinjal crop in the world after China (FAO 2012). Brinjal has a wide spectrum of insect pests (Srinivasan 2009). The brinjal shoot and fruit borer (BSFB), Leucinodes orbonalis (Guenée) (Lepidoptera: Crambidae), is the key pest that causes a significant yield loss to the tune of 70\% (Singh and Nath 2010). The infestation starts from the seedling stage till the final harvest, within few hours of the egg hatching, BSFB larvae bore into and feed on the tender shoots and the fruits of the brinjal plant. It is well known that farmers spray wide range of insecticides right from vegetative stage till last harvesting stage to protect the crop from the notorious BSFB, which leads to pesticide residue and insecticide resistance problems. Recently, a slow shift has been observed toward green chemicals including microbial-based products as the legal restrictions are imposed on synthetic chemicals and increased awareness among the consumers on food safety issues. Among the biopesticides, Bacillus thuringiensis (Bt) usage are in growing demand in recent years on vegetables and other high value crops where high level of safety and selectivity are desirable and resistance to synthetic insecticides is a problem (Elsayed et al. 2014). But their commercial application is limited due to their susceptibility to abiotic factors viz., temperature, humidity and UV rays. To overcome these bottlenecks, a hidden ecological role played by entomopathogenic bacteria as endophytes was sought. As the endophytes symbiotically live inside the plants thus gets protection against abiotic stresses and UV rays furthermore play a defensive role against insect pests. Endophyte-related research is promising but still in its budding stage. Only few studies demonstrated this novel approach of pest management (Praca et al. 2012). 
Recently, green fluorescent protein (GFP) has been widely used as a reporter for the in-situ detection and localization of bacterial cells in plants (Zhang et al. 2011) by using confocal laser scanning microscopy (CLSM) or fluorescence microscopy. Colonization of $B t$ as endophytes in plants, accompanied by the production of Cry proteins, opens new horizons for the development of novel pest-resistant crops. Therefore, colonization of $B t$ as endophyte in the plant is one of the possible approaches to combat the internal borer such as $L$. orbonalis. Hitherto no detailed studies are available on colonization of $B t$ on brinjal plant. Hence, the present study was conducted on the colonization of potential native $B t \mathrm{VKK}-\mathrm{BB} 2$ strain as endophyte and it's validation against BSFB in the brinjal plant.

\section{Methods}

\section{Bacterial strain and plasmid culture conditions}

Native B. thuringiensis strain VKK-BB2 (GenBank accession number KT714045) was retrieved from the bacterial stock of Insect Physiology and Molecular Biology Laboratory, Division of Entomology, IARI, New Delhi which was originally isolated from the cabbage aphid, Brevicoryne brassicae (Mandla et al. 2017). The BtVKK-BB2 strain was found to be the most potential out of 12 native strains screened against neonate of BSFB (data not shown here). Thus, BtVKK-BB2 strain was selected for $g f p$ tagging through electroporation. This strain is resistant to ampicillin and penicillin therefore maintained on Luria Bertani agar (LA) supplemented with ampicillin and penicillin (HiMedia Laboratories Pvt Ltd, India) at $50 \mu \mathrm{g} / \mathrm{ml}$ at $30{ }^{\circ} \mathrm{C}$. The Escherichia coli harboring pCAMBIA1302 plasmid (Fig. 1) was grown in Luria Bertani broth (LB) supplemented with $50 \mu \mathrm{g} / \mathrm{ml}$ kanamycin (HiMedia Laboratories Pvt Ltd, India) at $37^{\circ} \mathrm{C}$.

\section{Preparation of electrocompetent cells}

Electrocompetent cells were prepared according to the method described by Peng et al. (2009) with modification. Single colony of $B t$ VKK-BB2 was inoculated into $5 \mathrm{ml}$ of LB supplemented with ampicillin and penicillin at $50 \mu \mathrm{g} / \mathrm{ml}$ concentration and incubated overnight at $30^{\circ} \mathrm{C}$ in incubator shaker with $180 \mathrm{rpm}$. The overnight culture was diluted tenfold to get the optical density $\left(\mathrm{OD}_{600}\right)$ (Evolution $^{\text {TM }}$ 201/220 UV-Visible Spectrophotometers, Himedia Lab., India) of 0.02 at $600 \mathrm{~nm}$ ) and incubated at $30{ }^{\circ} \mathrm{C}$ with shaking at $200 \mathrm{rpm}$ until an $\mathrm{OD}_{600}$ was reached 0.4 . Then cell wall weakening agent glycine (10\%) (Sisco Research Laboratories Pvt Ltd, India) $15 \mathrm{ml}$ was added to the culture and kept for incubation for one more hour to get an $\mathrm{OD}_{600} 0.5$. The culture was chilled on ice for $5 \mathrm{~min}$, and the pellets were collected by centrifugation at $5000 \mathrm{~g}$ for $5 \mathrm{~min}$ at $4{ }^{\circ} \mathrm{C}$. The pellet was suspended in $10 \mathrm{ml}$ of ice-cold electroporation medium [272 mM sucrose, $0.5 \mathrm{mM} \mathrm{MgCl}, 0.5 \mathrm{mM} \mathrm{K}_{2} \mathrm{HPO}_{4}$ and $0.5 \mathrm{mM}$ $\mathrm{KH}_{2} \mathrm{PO}_{4}$ at PH 7.2 (Sisco Research Laboratories Pvt Ltd, India)], incubated on ice for $5 \mathrm{~min}$ and centrifuged at $5000 \mathrm{~g}$ for $5 \mathrm{~min}$ at $4{ }^{\circ} \mathrm{C}$ and this step was repeated thrice. The washed cells were re-suspended in electroporation medium to obtain cells concentration of approximately $1 \times 10^{10}$ cells $/ \mathrm{ml}$. The electrocompetent cells were aliquoted into $100 \mu \mathrm{l}$ and stored at $-80^{\circ} \mathrm{C}$ until use.

\section{Construction of $g f p$ expressing Bt VKK-BB2 strain}

An aliquot $(100 \mu \mathrm{l})$ of $B t$ VKK-BB2 electrocompetent cells were mixed with $1 \mu \mathrm{g}$ of plasmid of pCAMBIA 1302 and electroporated at $1.5 \mathrm{kV} / \mathrm{cm}$ and $200 \Omega, 25 \mu \mathrm{F}, 4.5 \mathrm{~ms}$ in $1 \mathrm{~mm}$ cuvette by using Gene-Pulser (Bio-Rad Laboratories, Richmond, CA) as per Peng et al. (2009). The electroporated cells were immediately mixed with $900 \mu \mathrm{l}$ of Luria broth and incubated at $30{ }^{\circ} \mathrm{C}$ for $3 \mathrm{~h}$. After the incubation, cells were plated on LB-agar plates supplemented with selective ampicillin, penicillin and kanamycin at $50 \mu \mathrm{g} / \mathrm{ml}$ concentration and incubated at $30{ }^{\circ} \mathrm{C}$ for overnight. Transformed colonies were selected by their resistance to kanamycin (Vector specific) in the medium, and fluorescence of the cells was corroborated under a fluorescence microscope.

\section{Confirmation of $g f p$ expressing cells of $B t$ VKK-BB2 strain}

The GFP gene-specific primers F-(5'TCAGTGGAGAGG GTGAAGGT3'), R-(5'GTGGTGGTGGCTAGGTTT GT3') were designed by NCBI blast and oligocalc (Kibbe 2007). The positive gfp expressing cells of BtVKK-BB2 were screened by using colony-PCR with GFP gene-specific primers by using PCR programme was initial denaturation at $94{ }^{\circ} \mathrm{C}$ for $3 \mathrm{~min}, 30$ cycles at $94{ }^{\circ} \mathrm{C}$ for $45 \mathrm{~s}$, annealing at $54.3{ }^{\circ} \mathrm{C}$ for $50 \mathrm{~s}$, extension at $72{ }^{\circ} \mathrm{C}$ for $55 \mathrm{~s}$ and final extension at $72{ }^{\circ} \mathrm{C}$ for $10 \mathrm{~min}$. Further, the putative positive cells were confirmed by the isolation of plasmid DNA (HighSpeed Plasmid Mini Kit Protocol) by overnight grown cells of BtVKK-BB2 into $5 \mathrm{ml}$ of LB containing ampicillin, penicillin and kanamycin $\left(50 \mu \mathrm{g} / \mathrm{ml}\right.$ of each) at $30{ }^{\circ} \mathrm{C}$ at $180 \mathrm{rpm}$. The plasmid of pCAMBIA1302 vector was visualized on $1 \%$ agarose gel prepared in $1 \times$ Tris-acetate-EDTA (TAE) buffer and stained by ethidium bromide $(0.5 \mu \mathrm{g} /$ $\mathrm{ml}$ ) through gel-electrophoresis in a gel documentation system (AlphaimagerTM). This plasmid was used for the PCR detection of gfp gene with the same PCR conditions described earlier.

\section{Plant inoculation}

The potting mixture was prepared by mixing soil, vermiculite and coco peat in 1:1:1 ratio and autoclaved for three times at $24 \mathrm{~h}$ interval. Seeds of brinjal (variety: Bhagyamati) were obtained from Vegetable Research Station, 


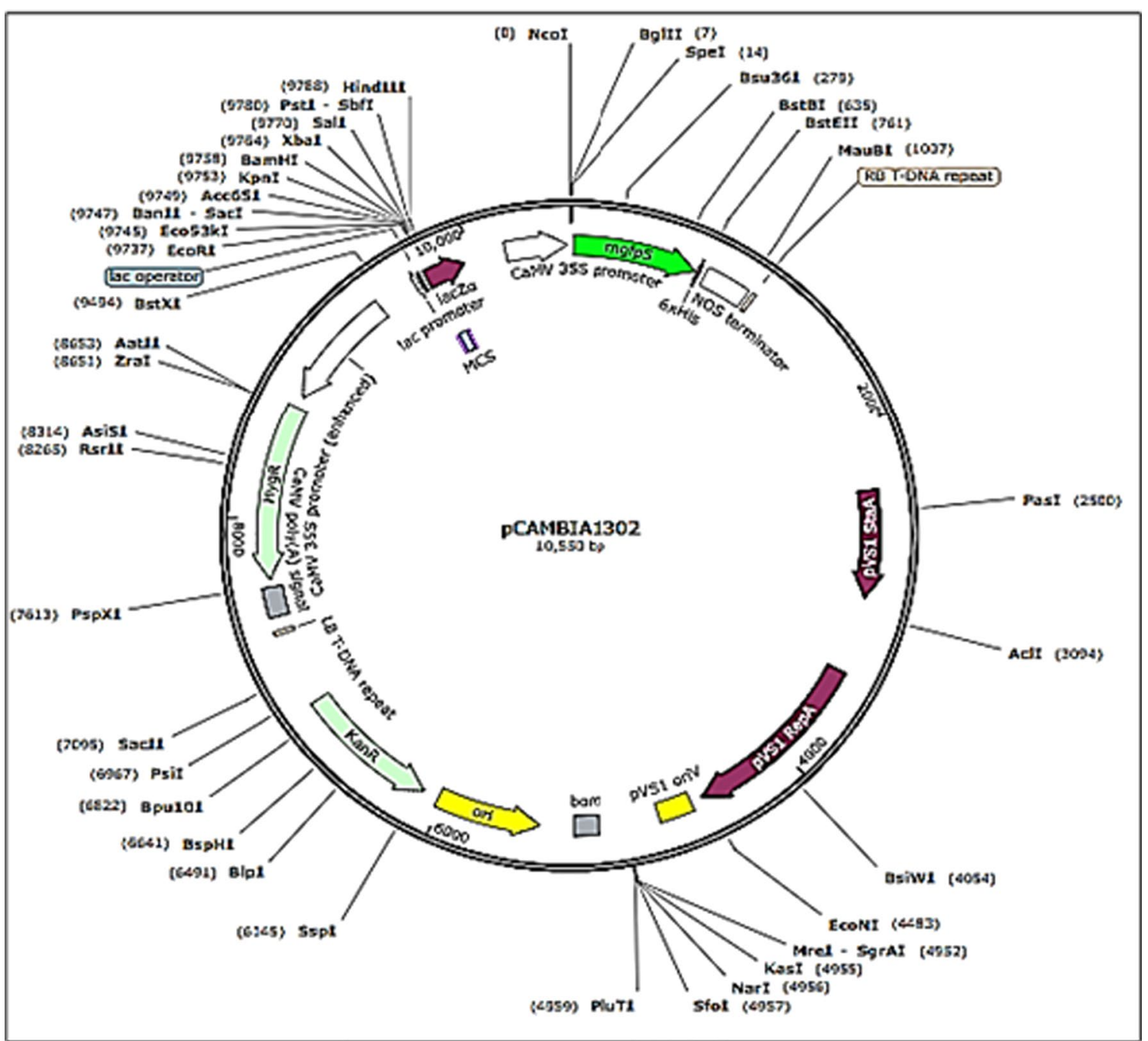

Fig. 1 Plasmid vector PCAMBIA 1302 with kanamycin resistance and GFP genes

SKLTS Horticultural University, Hyderabad. Two seeds were sown in the $20 \mathrm{~cm} \times 10 \mathrm{~cm}$ size pots and 10 pots per treatment were maintained during the experiment. The seedlings were maintained in plant growth chamber under $12 \mathrm{~L}: 12 \mathrm{D}$ at $30{ }^{\circ} \mathrm{C}$ temperature and $65-70 \%$ relative humidity. Pots were watered, whenever the top 2-3 inches soil was found dry. $g f p$-tagged BtVKK-BB2 (gfp-BtVKK-BB2) strain was inoculated by three different methods viz., seed treatment, soil drenching and foliar application as given below.

\section{Seed treatment}

Seeds were washed with tap water thrice, followed by $70 \%$ ethanol for 2 min and $2 \%$ sodium hypochlorite for $5 \mathrm{~min}$ and finally washed with sterile distilled water (sdw) thrice. A $g f p-B t \mathrm{VKK}-\mathrm{BB} 2$ strain was grown in LB with selective antibiotics (ampicillin, penicillin and kanamycin) until $\mathrm{OD}_{600}$ of 0.8 and diluted to achieve the required concentration $\left(10^{8} \mathrm{cfu} / \mathrm{ml}\right)$ by serial dilution method before use. The surface sterilized seeds were soaked in the GFP-BtVKK-BB2 suspension $\left(10^{8} \mathrm{cfu} / \mathrm{ml}\right)$ for $3 \mathrm{~h}$ and dried on sterilized tissue for sowing in soil.

\section{Soil application}

Five $\mathrm{ml}$ of $g f p-B t \mathrm{VKK}-\mathrm{BB} 2\left(10^{8} \mathrm{cfu} / \mathrm{ml}\right)$ was given near the root zone of 30-day-old seedling once a week. 


\section{Foliar application}

The leaves of 30-day-old seedling were sprayed once and twice a week with $g f p-B t \mathrm{VKK}-\mathrm{BB} 2\left(10^{8} \mathrm{cfu} / \mathrm{ml}\right)$ till they became wet.

\section{Soil and foliar application}

Five $\mathrm{ml}$ of $g f p-B t \mathrm{VKK}-\mathrm{BB} 2\left(10^{8} \mathrm{cfu} / \mathrm{ml}\right)$ was given to 30-day-old seedlings near the root zone as well as leaves were sprayed with it till, they became wet. In all the treatments, respective controls were treated with sdw.

\section{Visualization of $g f p$-tagged BtVKK-BB2 in plant tissue using confocal laser scanning microscopy (CLSM)}

Samples of leaves and shoots $(2 \mathrm{~cm})$ were selected randomly from inoculated and control plant groups at 5,10 , 15 and 30 days after inoculation (DAI) by various treatments. Sections of surface-sterilized leaf, and shoot tissues emitting green fluorescence were observed using $488 \mathrm{~nm}$ excitation and $500-550 \mathrm{~nm}$ emission wavelength filter settings using CLSM (Leica).

\section{Confirmation of cry1 gene in BtVKK-BB2 colonies recovered from leaves}

Samples of 2-cm leaves and stems were selected randomly from respective treated and control plant groups at $3,10,15$ and 30 days after inoculation. The leaves were surface sterilized with $70 \%$ alcohol and $2 \%$ sodium hypochlorite solution followed by three washes of sdw. Surface-sterilized leaves were homogenized in sdw and supernatant was plated on selective antibiotic plates [penicillin $(50 \mu \mathrm{g} / \mathrm{ml})$ ]. Plates were incubated at $30{ }^{\circ} \mathrm{C}$ for 48-72 h. The fluorescence of the cells of colonies thus recovered from treated plants was verified under a fluorescence microscope in order to confirm that the re-isolated colonies were of gfp-tagged $B t \mathrm{VKK}-\mathrm{BB} 2$.

To ensure the presence of $c r y 1$ gene in the recovered colonies from leaves $c r y 1$ gene-specific primers FP-CAT GATTCATGCGGCAGATAAAC; RP-TTGTGACAC TTCTGCTTCCCATT (Bravo et al. 1998) were used. A loopful cell was transferred to $100 \mu \mathrm{l}$ of sdw, and the mixture was frozen for $20 \mathrm{~min}$ at $-80^{\circ} \mathrm{C}$ and then transferred to boiling water for $10 \mathrm{~min}$ to lyse the cells. The resulting cell lysate was centrifuged at 10,000 rpm for $30 \mathrm{~s}$ and supernatant was used as a DNA template in the PCR. DNA template $(10 \mu \mathrm{l})$ was mixed with reaction mixture of $4.3 \mu$ l consisting of Taq assay buffer $(10 \times)$ with $\mathrm{MgCl}_{2}(15 \mathrm{mM}), 1 \mu \mathrm{l}$ dNTPs $(10 \mathrm{mM}), 1 \mu \mathrm{l}$ of each primer $(10 \mathrm{pM}), 0.2 \mu \mathrm{l} \mathrm{Taq}$ DNA polymerase $(5 \mathrm{U} / \mu \mathrm{l})$ and $7.5 \mu \mathrm{l}$ nuclease free water. The reactions were placed in a thermocycler (Flexigene Techne, UK) programmed as initial denaturation at $94{ }^{\circ} \mathrm{C}$ for $5 \mathrm{~min}$ followed by 35 cycles of denaturation at $94{ }^{\circ} \mathrm{C}$ for $1 \mathrm{~m}$, annealing at $50^{\circ} \mathrm{C}$ for $1 \mathrm{~min}$, extension at $72{ }^{\circ} \mathrm{C}$ for $2 \mathrm{~min}$ and a final extension at $72{ }^{\circ} \mathrm{C}$ for $5 \mathrm{~m}$. After amplification, $2 \mu \mathrm{l}$ of loading buffer ( $0.5 \%$ bromophenol blue in glycerol $50 \%)$ was added to $5 \mu \mathrm{l}$ of each amplified PCR product and was electrophoresed (at $70 \mathrm{~V}$ for $10 \mathrm{~min}$, followed by $90 \mathrm{~V}$ for $45 \mathrm{~min}$ ) on a $1 \times$ Tris-acetate-EDTA (TAE with ethidium bromide) buffer in $1.2 \%$ agarose gel. Gels were visualized in a gel documentation system (AlphaimagerTM) and analyzed with AlphaEaseFC.

\section{Rearing of Leucinodes orbonalis and evaluation of colonized $g f p$-BtVKK-BB2 strain in brinjal by detached leaf assays}

Infested brinjal fruits were collected from the fields of IARI, New Delhi brought to insectary and kept in plastic containers till the larvae comes out of fruits and become pupae. The pupae were separated and kept in a small plastic container lined with blotting paper till the adult emergence. On emergence, 25-30 adults were transferred in mating jars $(15 \mathrm{~cm}$ diameter and $20 \mathrm{~cm}$ height) covered with cotton cloth having $10 \%$ fortified honey solution for adult feeding. A fresh brinjal leaf was placed daily for egg laying and old leaf with eggs was removed from mating jar and kept in a plastic container covered with tissue paper till hatching. The neonates were reared on semi synthetic diet as per Sethi et al. (2016) with some modification till pupation (Additional file 1: Table S1). The culture was maintained under controlled laboratory condition, i.e., at $27 \pm 2{ }^{\circ} \mathrm{C}, 65 \pm 5 \% \mathrm{RH}$ and $14: 10$ $\mathrm{L}: \mathrm{D}$ photoperiod. The neonates $(<24 \mathrm{~h}$ old $)$ were used for bioassays.

The leaves were detached from brinjal plants in which BtVKK-BB2 strain was colonized as endophytes by different inoculation methods viz., seed treatment (ST), soil application (SA), foliar spray (FS), SA + FS and control plants of brinjal. Three leaves were detached randomly from each treatment. On each leaf, 10 neonates were released and kept in plastic plates and covered with lid. The observations were taken daily till 7 days.

\section{Results}

Confirmation of GFP gene in positive transformants

Transformation of strain VKK-BB2 by electroporation with plasmid $\mathrm{p}^{\text {CAMBIA1302 }}$ was successful. The expected fluorescence of $B t \mathrm{VKK}-\mathrm{BB} 2$ transformants harboring $\mathrm{p}^{\text {CAMBIA1302 }}$ was confirmed by the fluorescence under CLSM observation and plasmid extraction (Fig. 2A, B) and amplification of GFP gene of $644 \mathrm{bp}$ from positive bacterial culture grown on Luria broth with selective antibiotic kanamycin $(50 \mu \mathrm{g} / \mathrm{ml})$ (Fig. 2C). These $g f p$ tagged $B t \mathrm{VKK}-\mathrm{BB} 2$ was used to inoculate brinjal seedling by various methods in brinjal. 


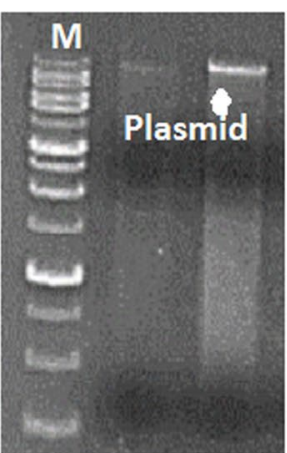

A

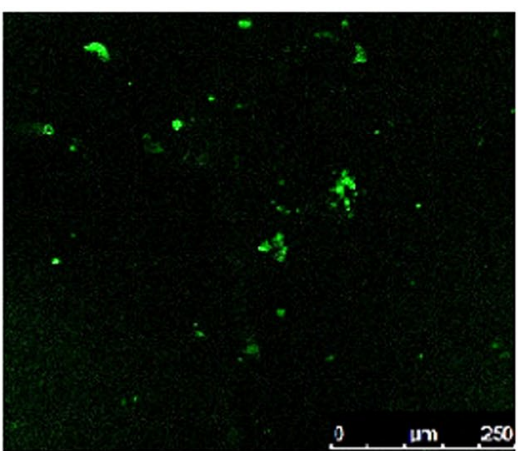

B

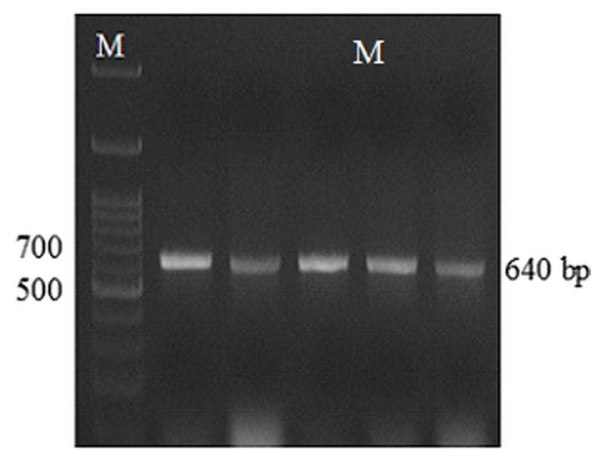

C

Fig. 2 A Gel image of plasmid extracted from GFP-tagged BtVKK-BB2 strain; B GFP-tagged BtVKK-BB2 cells under confocal microscope; C GFP gene amplification in positive colonies after transformation

\section{Visualization of GFP-tagged BtVKK-BB2 in plant tissue}

CLSM studies on $g f p-B t \mathrm{VKK}-\mathrm{BB} 2$ were carried out in the leaf and shoot tissues of brinjal and tagged $B t \mathrm{VKK}-\mathrm{BB} 2$ cells were detected in all the methods, i.e., seed treatment, soil application and foliar spray. Whereas, stem and leaf tissues of untreated brinjal seedlings did not show any fluorescent signals during these studies (Fig. 3F). Thus, established that BtVKK-BB2 strain has endophytic ability and it will translocate from seed to shoot as well as leaves and subsist even up to 30 days after seed
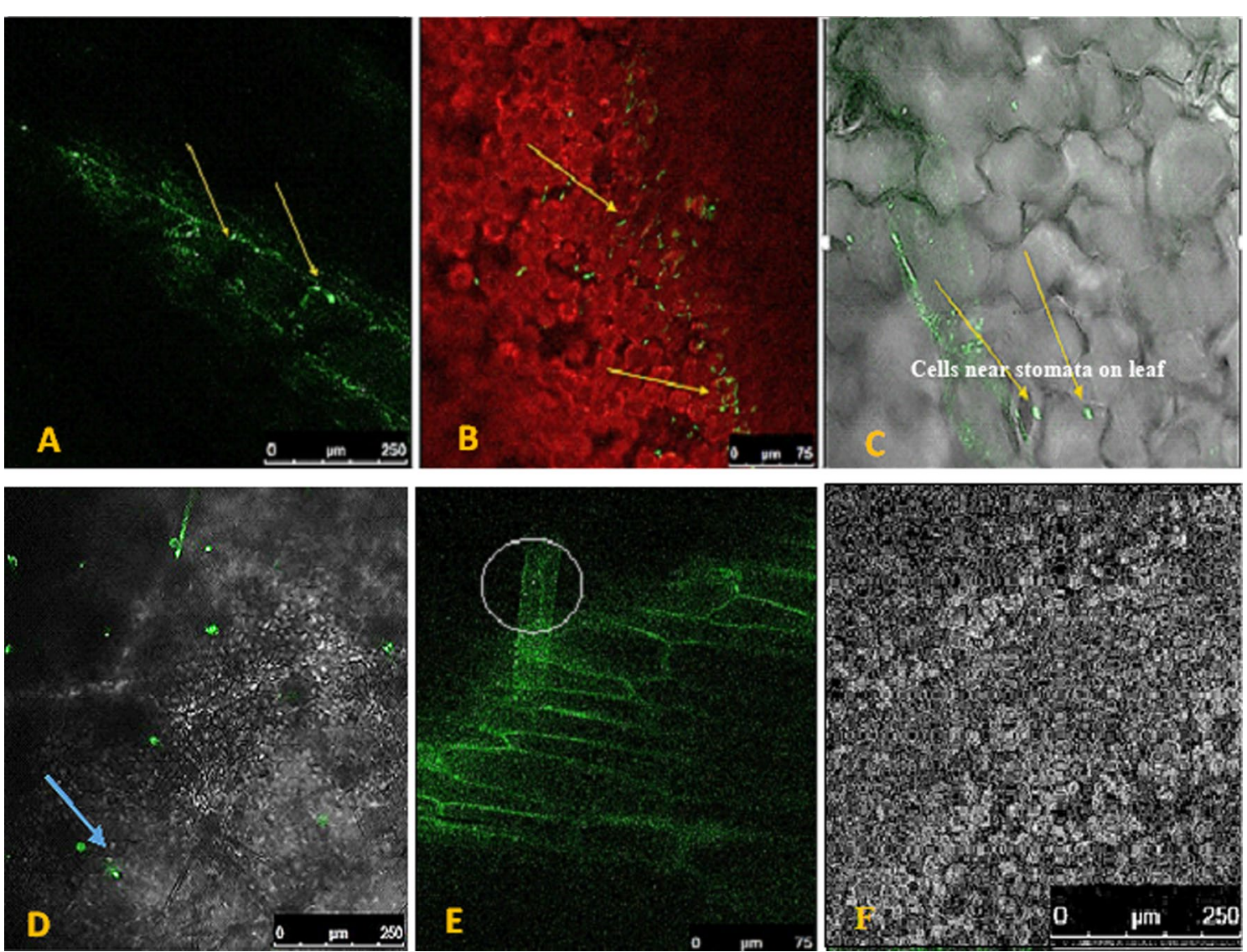

Fig. 3 Confocal microscopy images of brinjal shoot and leaves tissue colonized by GFP-tagged VKK-BB2 cells by seed inoculation method. 15 days after emergence of seedlings (A-C); A Shoot; $\mathbf{B}$ and $\mathbf{C}$ Leaf. 30 days after emergence of seedlings (D-F); $\mathbf{D}$ Shoot; $\mathbf{E}$ Leaf; $\mathbf{F}$ Leaf (control) 
germination. Moreover, have the ability to migrate from rhizosphere to leaves after soil application. However, the fluorescence signals were reduced over the period of time in all the inoculation methods. The $g f p$-tagged $B t$ cells could be distinguished easily from the background fluorescence of the leaf and stem and showed different colonization patterns with different inoculation methods. The CLSM images showed that there was a difference in fluorescence signals in plant parts as per inoculation methods. On the other hand, no florescence was observed in the negative control of all inoculation methods.

The leaf and stem tissues which were collected on 15 and 30 days after seed treatment were detected with fluorescing VKK-BB2 cells (Fig. 3A-E). Few cells appeared to be embedded in between the tissues in leaf (Fig. 3B) and xylem cells (Fig. 3E). The bright fluorescence signals in stem (Fig. 3A) were reduced on 30th DAI (Fig. 3D). In addition, the CLSM images showed that the $g f p$-BtVKKBB2 could also colonize near stomata of the leaf (Fig. 3C). The low fluorescence signals on 30th DAI indicated that there was reduction in colonization. Pertaining to soil application of $g f p-B t \mathrm{VKK}-\mathrm{BB} 2$ as single dose, CLSM images of plant parts revealed that at 3rd day after inoculation, stem and leaf tissues were detected with $g f p$ $B t$ VKK-BB2 cells while on 10th DAI the signals were less due to low number of colonies and on 15th DAI, no fluorescence was detected (Fig. 4). Whereas, in single dose of foliar spray bright fluorescence has been exhibited by brinjal leaf tissues on 3rd DAI, 10th DAI even up to 15th DAI (Fig. 5A-C).

Further, it has been noticed that when $g f p-B t \mathrm{VKK}-\mathrm{BB} 2$ was inoculated to soil twice in a week, there was a slight increase in fluorescence signals on 3rd DAI over the single dose of soil application but there was no much variation in colonies at 10th DAI over the single dose. On the other hand, strong fluorescence signals were detected in brinjal leaf tissues on 3rd, 10th and 15th DAI with two doses of foliar spray per week over the single dose. The brinjal plant treated with SA+FS twice/week showed more fluorescence up to 15th DAI in leaves which was
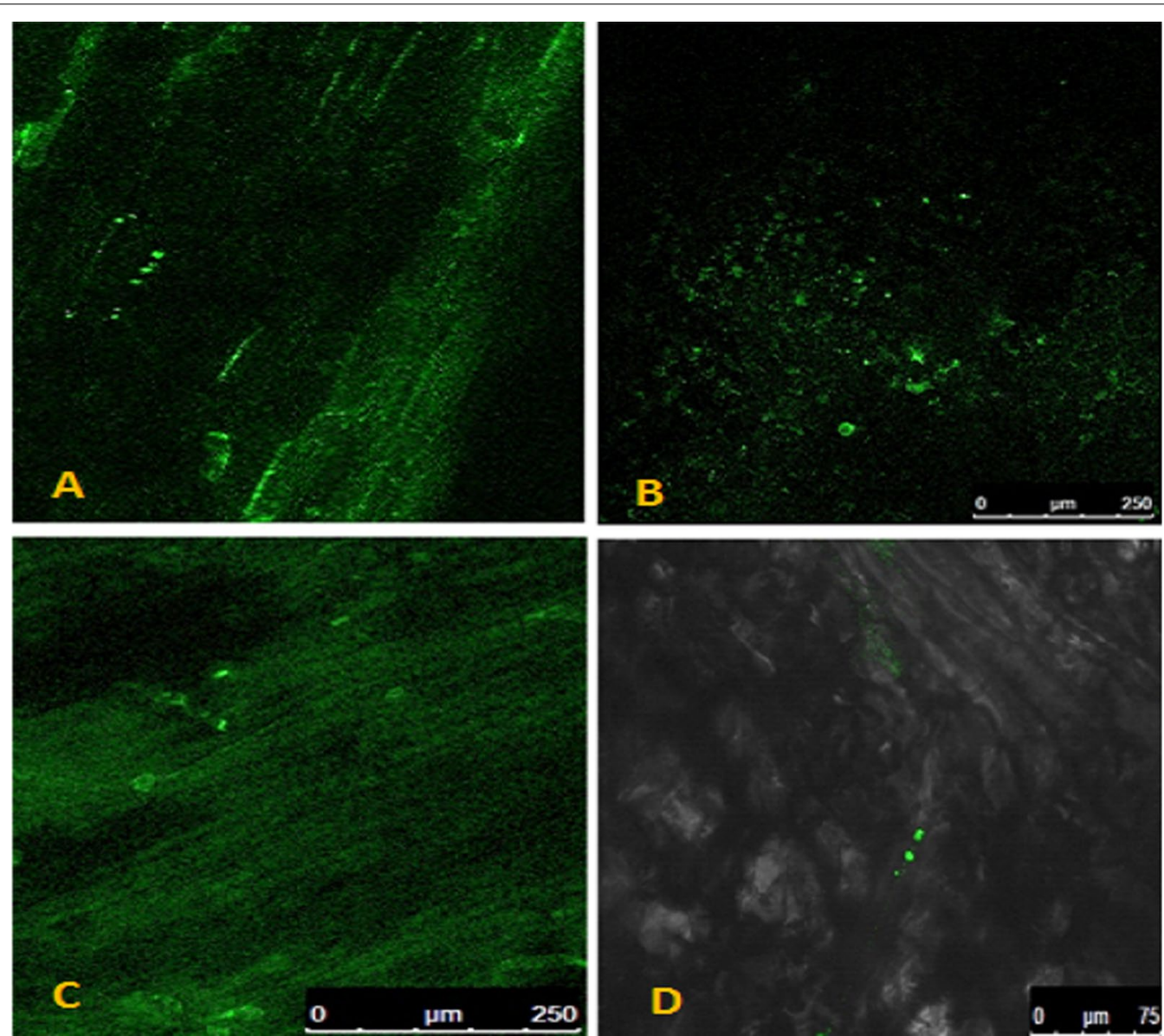

Fig. 4 Confocal microscopy images of brinjal shoot and leaves colonized by GFP-tagged VKK-BB2 cells by soil inoculation method. A Shoot (3DAI); B Leaf (3DAl); C Shoot (10 DAl); D Leaf (10 DAl) 

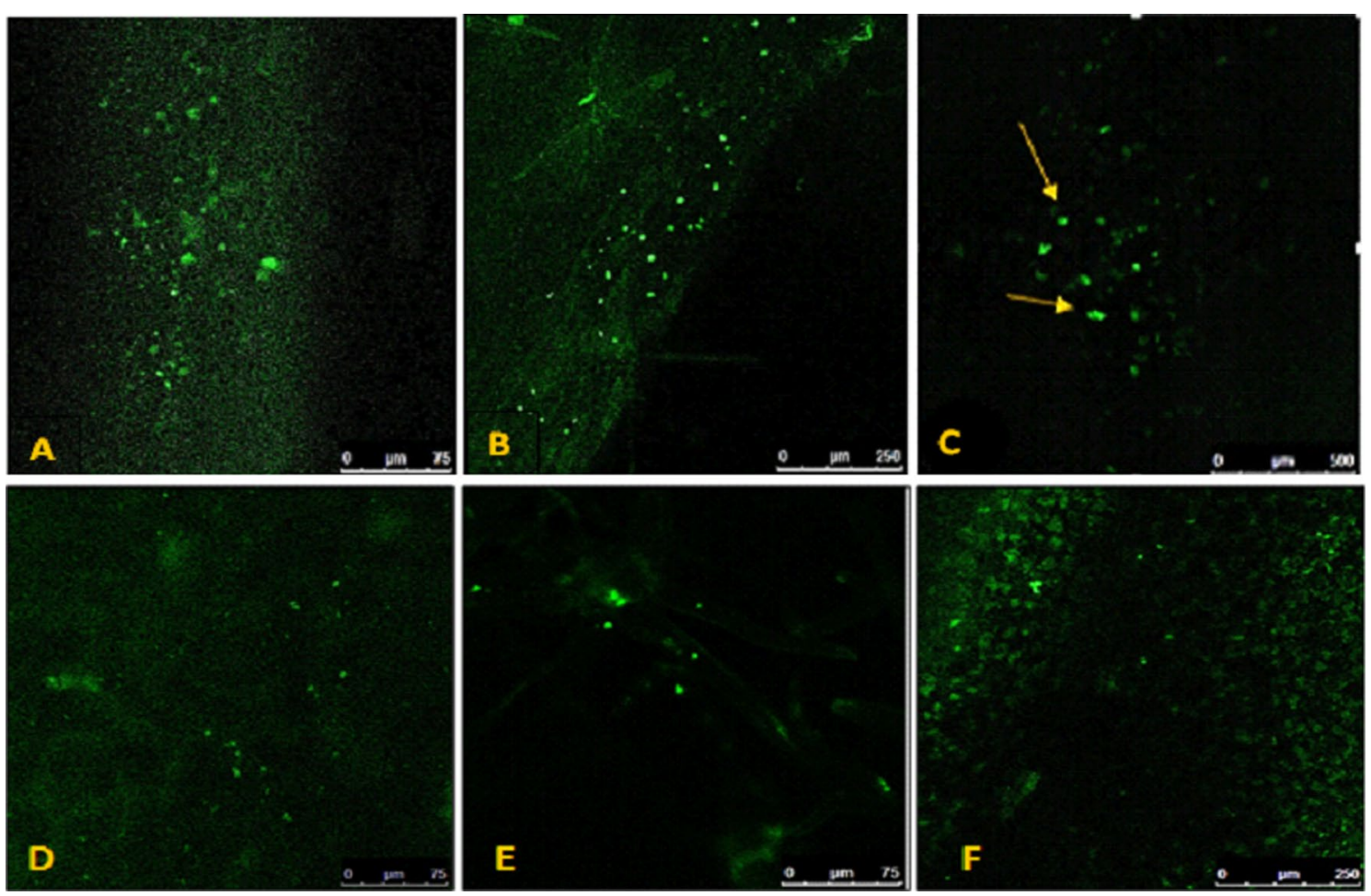

Fig. 5 Confocal microscopy images of brinjal leaves colonized by GFP-tagged VKK-BB2 cells by foliar spray method @ single application (A-C) [A 3 days after inoculation; $\mathbf{B} 10$ days after inoculation; C 15 days after inoculation] and twice/week (D-F) [D 3 days after inoculation; E 10 days after inoculation; $\mathbf{F} 15$ days after inoculation]

found to be equivalent to that of foliar spray twice/week treatment (Fig. 5D-F; Fig. 6). Further, GFP positive cells were detected in stem sections up to 10th DAI only but not seen when tested up to 15 th DAI. These results suggested that $B t$-VKK-BB2 was a systemic colonizer of brinjal through seed treatment, soil application and foliar spray.

Confocal microscopic studies indicated that $g f p$ $B t \mathrm{VKK}-\mathrm{BB} 2$ cells were efficiently colonized brinjal leaf and colonization was detected up to 10 days in soil application while 15 days in foliar spray, whereas it was up to 30 DAI in seed treatment. However, the bright fluorescence was seen in plants treated by foliar spray followed by seed treatment and soil application.

\section{Confirmation of cry gene in BtVKK-BB2 colonies recovered from leaves through PCR}

BtVKK-BB2 colonies which were re-isolated from leaves collected from seed inoculated plant, soil application plant as well as foliar-sprayed plants amplified expected amplicon size of $276 \mathrm{bp}$ of $c r y 1$ gene (Fig. 7). Thus, confirmed that BtVKK-BB2 could persist and produce Cry toxins in the leaves in all the inoculation methods.

\section{Bioassays with brinjal plants inoculated}

\section{with $g f p-B t V K K-B B 2$ against Leucinodes orbonalis}

The efficacy of $g f p$-BtVKK-BB2 established as endophyte by different inoculation methods in brinjal plants was carried out by detached leaf feeding assays as shown in Fig. 8 against neonates of BSFB. The observations on feeding of neonates on leaves in all the inoculation methods indicated that the larvae were found to feed by tunneling of leaves including untreated control but the dead larvae were seen on leaves from 5 th day to 7 th day after release on leaves. $26.85-39.26 \%$ mortality was observed on 7 days after treatment (Fig. 9).

\section{Discussion}

During the past decade, numerous studies have been carried out on plant disease control, growth promotion and biomass improvement through use of bacterial endophytes, and many useful strains have been identified, resulting in several commercial products (Mei and Flinn 2010; Pérez-García et al. 2011; Alfonzo et al. 2012; Li et al. 2012). Recently various reports demonstrated that entomopathogenic fungi and bacteria can be easily established inside plants and can be used for management of insect pests (Praça et al. 2012; Russo et al. 2021; ResquínRomero et al. 2016; Sánchez-Rodríguez et al. 2018; Sauka 

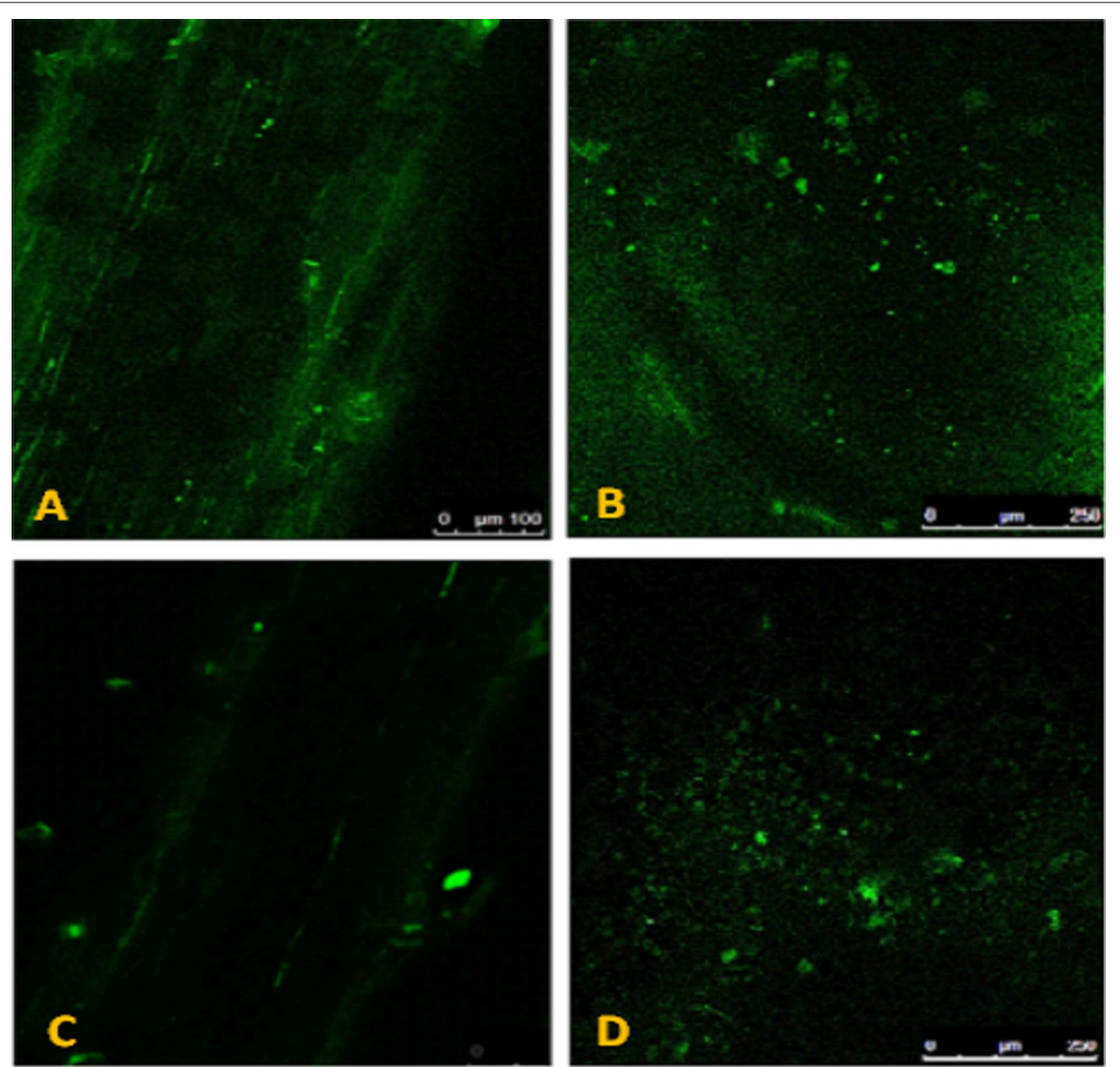

Fig. 6 Confocal microscopy images of brinjal shoot and leaves colonized by GFP-tagged VKK-BB2 cells by soil + foliar application method. A Shoot (10 DAl); B Leaf (10DAl); C Shoot (15 DAl); D Leaf (15 DAl)

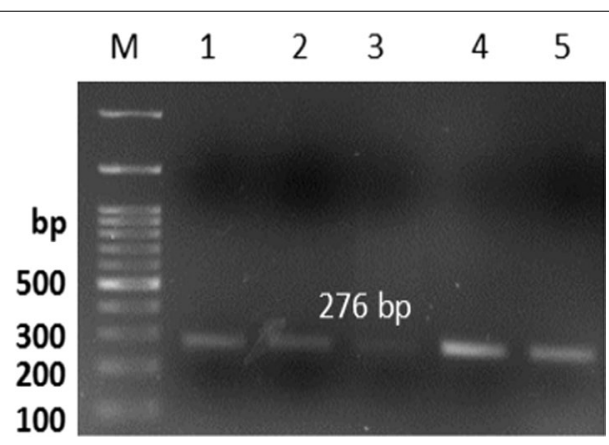

Fig. 7 Amplification of cry 1 gene in BtVKK-BB2 colonies re-isolated from leaf samples of different treatments (Lane 1-5) and Lane M: Marker

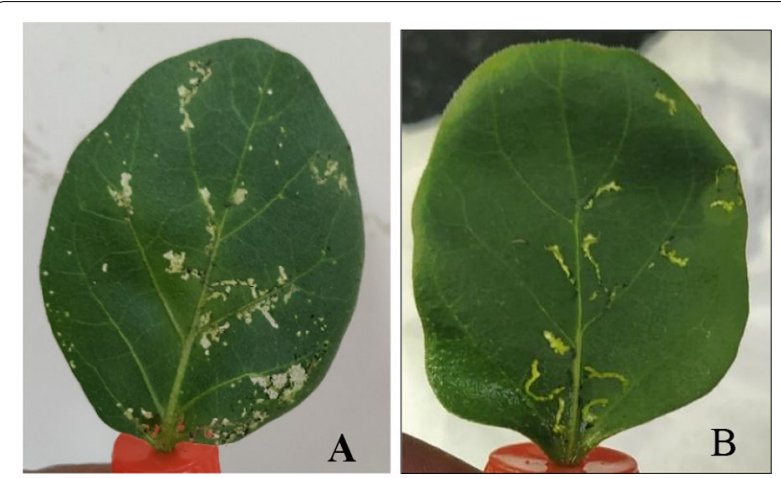

Fig. 8 Detached leaf bioassay showing leaf damage by neonates of Leucinodes orbonalis in A Control; B BtVKK-BB2-colonized plant 


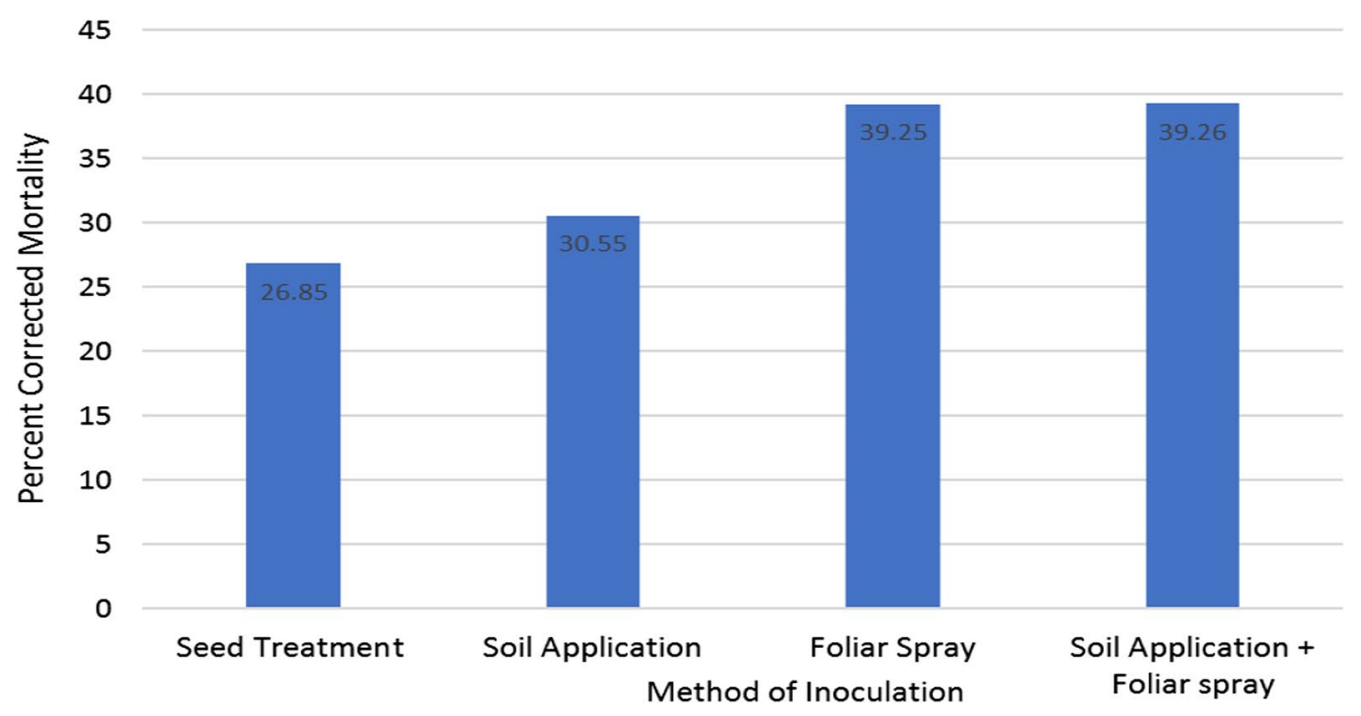

Fig. 9 Effect of different inoculation methods used for establishment of GFP-BtVKK-BB2 strain as endophytes in brinjal plant on its efficacy against neonates of Leucinodes orbonalis

and Benintende 2017). In view of that, bacterial (Bacillus spp.) have received increasing attention as a promising alternative to chemical control and offer a good option as biocides over transgenes. Scientific advancement of endophytic nature of bacterial (Bacillus spp.) open new avenue for the pest control, as once the endophytes are inoculated into plants, they will self-perpetuate and interfere with biosynthetic pathways which results in systemic production and translocation of secondary metabolite, enhancement of micronutrient content and production of toxins throughout the plant, which do not allow the ingestion by insect pests. But the studies are limited with respect to the endophytic ability of entomopathogenic $B$. thuringiensis showing resistance against insect species. In the present study, an attempt has been made to colonize potential native Bt strain VKK-BB2 in brinjal plant and validated by CSLM, cry1 gene amplification and feeding bioassay.

The long-term persistence of bacteria in the sampled leaf and stem tissues through seed treatment in the present study clearly demonstrated that they were able to colonize rapidly and can compete with other internal microbes inside the seedling. The seed endophytic microbial load was probably low during inoculation of $g f p-$ $B t$ VKK-BB2 to the seed which might have allowed the inoculant strain to thrive inside the seedling which could be visualized under CLSM after 4th week of inoculation. Similarly, Praça et al. (2012) revealed that the four Brazilian B. thuringiensis strains were able to colonize cabbage seedlings through seed treatment and further confirmation of presence of vegetative cells, spores and crystals of the strains in different parts of cabbage seedlings has been done by using scanning electron microscopy. According to previous reports, the bacterial isolates that have selective ability to use the nutrients released during seed germination have an advantage in colonizing the internal tissues of seed (Subrahmanyan et al. 1983). However, in the present study, at 5th week after seed treatment no fluorescence signals were perceived including stem and leaf tissues.

In case of soil application, the probable route for systemic colonization in the plant might be the vascular system of the plant and xylem vessels of stem. Thus, the bacterium could be able to translocate more possibly, through the xylem up to the stem and leaves of the plant and persisted up to 10th day after single inoculation. The fluorescence signals in the leaf tissues clearly demonstrated that the bacteria have shown rhizosphere competence against endophytic microbes in root, stem and leaf tissues. However, the inoculant strain $g f p-B t \mathrm{VKK}$ BB2 has not been traced at 15th day of inoculation which could be probably due to the high competition from the plant associated microbes. Earlier, it has been reported that plant growth promotion ability of $B$ thuringiensis in legumes and $B t$ that has been inoculated into legumes rhizosphere not only colonize its root interior, but also improve root nodulation and plant growth (Mishra et al. 2009). Monnerat et al. 2009 reported the capability of $B t$ kurstaki strain HD-1 marked by GFP that inhabit plants as an endophyte. After successful inoculation of cotton and cabbage seedlings to the roots, GFP marked bacteria has been visualized from all parts of the plant and confirmed the translocation of bacterium in the xylem. 
In the foliar spray, the more fluorescent signals were detected after 1 week of inoculation due to high colonies of bacterium inside the leaf tissues. So, it can be ascribed that the bacterium could reach leaf tissues which might be due to less competition compared to the soil application method. Moreover, it has been predicted that the bacteria made the entries through stomata and signals were more near the stomatal walls as the colonization of bacteria was confirmed by CLSM images. While, on 15th day after inoculation, relatively low signals were recovered in leaf tissues due to decline in the number of colonies of inoculant inside the leaf tissue. The inoculant strain could not persist inside the plant for longer period might be due to availability of limited nutrients or inhibitory effects of the diverse secondary metabolites of plant and antimicrobial secretions from surrounding microbes. Maduell et al. (2008) reported that few green fluorescent cells were detected through epifluorescence microscopy of the given leaf surfaces at 2 days after foliar spray of $B$. thuringiensis strain on bean leaves. Further, it has been added that $B t$ was unable to grow at relatively low nutrient concentrations on bean leaf surfaces compared to other epiphytic microbes. Nevertheless, various lines of evidence suggest that $B$. thuringiensis is unable to access nutrients that might be available on leaves.

The present study indicated that tagging of insecticidal $B t$ strain and CLSM imaging to visualize the endophytic ability of bacteria inside the brinjal plant is believed to be a potential tool for analyzing the colonization and localization of beneficial microbial population. Moreover, ability of $B t$ to systemically colonize inside the plant tissues also allow protection of $B t$ strain VKK-BB2 from environmental factors which are known to influence the colonization. Additionally, feeding bioassays with BtVKK-BB2-inoculated brinjal plants of different treatments ensure its insecticidal ability, which further has to be enhanced by increasing the rate of establishment in plant tissues. However, $B t$ was not detected inside the plant parts 2 weeks after soil application and foliar sprays raised the questions on survival fitness of $B t$ in terms of its interaction with other plant associated microbes and plant chemistry which are yet to be explored. Among the various methods, the seed treatment was better method in terms of long-term colonization inside the leaves and followed by foliar spray as the colonization was found to be more in the leaves.

\section{Conclusions}

Establishment of native $B t$ strain as endophytes in plants opens new horizons for the development of a novel pest-resistant crops which could be an alternative to $\mathrm{Bt}$ transgenic crops. However, the level of insect mortality reported in current study was not high as these were achieved by single-dose inoculum. Thus, further optimization of $B t$ strain concentration is required to attain viable level of control of $L$. orbonalis in the field conditions. Moreover, inoculation of Bt through seed and foliar spray has to be further explored against larval herbivores especially internal borers to enhance its biocontrol potential through endophytic mediation which may open a novel set of strategies to control the insect pests in a sustainable way.

\section{Abbreviations \\ Bt: Bacillus thuringiensis; BSFB: Brinjal shoot and fruit borer; CFU: Colony form- ing unit; CLSM: Confocal laser scanning microscopy; DAl: Day after inoculation; min: Minute; msec: Milli second; sec: Second; sdw: Sterilized distilled water; $\mu g$ : Microgram; $\mu$ l: Microlitre; Fig.: Figure; GFP: Green florescent protein.}

\section{Supplementary Information}

The online version contains supplementary material available at https://doi. org/10.1186/s41938-022-00512-y.

Additional file 1: Table S1. Composition of semi synthetic diet for mass rearing of Leucinodes orbonalis.

\section{Acknowledgements}

SP is grateful to the Post Graduate School and Director, ICAR-Indian Agricultural Research Institute (New Delhi) for providing financial support to carry out the Ph.D. programme. The authors are grateful to the Director, ICAR-Indian Agricultural Research Institute, New Delhi, for providing necessary infrastructure and facilities.

\section{Authors' contributions \\ VKK and SP designed the project, SP performed the experiment with support of AKK, JS \& DS analyzed the data and interpreted the results. SP and VKK wrote the manuscript. All the authors critically read and approved the final manuscript.}

Funding

Not applicable.

Availability of data and materials

The datasets used during the current study are available from the corresponding author on reasonable request.

\section{Declarations}

Ethics approval and consent to participate

Not applicable.

Consent for publication

Not applicable.

Competing interests

The authors declare that they have no competing interests.

Author details

${ }^{1}$ Division of Entomology, ICAR-Indian Agricultural Research Institute, New Delhi 110012, India. ${ }^{2}$ Division of Plant Pathology, ICAR-Indian Agricultural Research Institute, New Delhi, India.

Received: 3 December 2021 Accepted: 31 January 2022

Published online: 05 February 2022 


\section{References}

Alfonzo A, Piccolo SL, Conigliaro G, Ventorino V, Burruano S, Moschetti G (2012) Antifungal peptides produced by Bacillus amyloliquefaciens AG1 active against grapevine fungal pathogens. Ann Microbiol 62:1593-1599

Bravo A, Sarabia S, Lopez L, Ontiveros H, Abarca C, Ortiz A et al (1998) Characterization of cry genes in a Mexican Bacillus thuringiensis strain collection. Appl Environ Microbiol 64(12):4965-4972

Choudhary B, Gaur K (2009) The development and regulation of Bt Brinjal in India (Eggplant/Aubergine). ISAAA Brief No.38, Ithaca, NY

Elsayed EA, Othman NZ, Malek R, Awad HM et al (2014) Bioprocess development for high cell mass and endospore production by Bacillus thuringiensis var israelensis in semi-industrial scale. J Pure Appl Microbiol 8(4):2773-2783

FAO (2012) Assessing the potential of insects as food and feed in assuring food security. Summit report, Technical consultation meeting, 23-25 January, 2012. FAO, Rome, Italy

Kibbe WA (2007) OligoCalc: an online oligonucleotide properties calculator. Nucleic Acids Res 35:W43-46

Li HY, Shen M, Zhou ZP, Li T, Wei YL, Lin LB (2012) Diversity and cold adaptation of endophytic fungi from five dominant plant species collected from the Baima Snow Mountain, Southwest China. Fungal Divers 54:79-86

Maduell P, Armengol G, Llagostera M, Orduz S, Lindow S (2008) Bacillus thuringiensis is a poor colonist of leaf surfaces. Microb Ecol 55(2):212-219

Mandla R, Mittal A, Veeranna D, Kalia V (2017) Characterization of potential native Bacillus thuringensisstrains isolated from insect cadavers against cotton aphid Aphis gossypii Glover (Hemiptera: Aphididae). Indian J Entomol 80(2):177-184

Mei C, Flinn BS (2010) The use of beneficial microbial endophytes for plant biomass and stress tolerance improvement. Recent Pat Biotechnol 4:81-95

Mishra PK, Mishra S, Selvakumar G, Bisht JK, Kundu S, Gupta HS (2009) Coinoculation of Bacillus thuringeinsis-KR1 with Rhizobium leguminosarum enhances plant growth and nodulation of pea (Pisum sativum L.) and lentil (Lens culinaris L.). World J Microbiol Biotechnol 25(5):753-761

Monnerat RG, Soares CMS, Gomes ACM, Jones G, Martins E, Praca L, Berry C (2009) Translocation and insecticidal activity of Bacillus thuringiensis bacteria living inside of plants. Microb Biotechnol 2:1560-1562

Peng D, Luo Y, Guo S, Zeng H, Ju S, Yu Z, Sun M (2009) Elaboration of an electroporation protocol for large plasmids and wildtype strains of Bacillus thuringiensis. J Appl Microbiol 106(6):1849-1858

Pérez-García A, Romero D, Vicente A (2011) Plant protection and growth stimulation by microorganisms: biotechnological applications of Bacilli in agriculture. Curr Opin Biotechnol 22:187-193

Praca LB, Gomes ACM, Cabral G, Martins ES, Sujii ER, Monnerat RG (2012) Endophytic9 colonization by Brazilian strains of Bacillus thuringiensis on cabbage seedlings grown in vitro. Bt Res 3:11-19

Resquín-Romero G, Garrido-Jurado I, Delso C, Ríos-Moreno A, QuesadaMoraga E (2016) Transient endophytic colonizations of plants improve the outcome of foliar applications of mycoinsecticides against chewing insects. J Invertebr Pathol 136:23-31

Russo ML, Jaber LR, Scorsetti AC, Vianna F, Cabello M, Pelizza SA (2021) Effect of entomopathogenic fungi introduced as corn endophytes on the development, reproduction, and food preference of the invasive fall armyworm Spodoptera frugiperda. J Pest Sci 94:859-870

Sánchez-Rodríguez AR, Raya-Díaz S, Zamarreño ÁM, García-Mina JM, del Campillo MC, Quesada-Moraga E (2018) An endophytic Beauveria bassiana strain increases spike production in bread and durum wheat plants and effectively controls cotton leafworm (Spodoptera littoralis) larvae. Biol Control 116:90-102

Sauka DH, Benintende GB (2017) Diversity and distribution of lepidopteranspecific toxin genes in Bacillus thuringiensis strains from Argentina. Rev Argent Microbiol 49:273-281

Sethi T, Kalia V, Singh AK, Gujar GT (2016) In vitro rearing of brinjal shoot and fruit borer, Leucinodes orbonalis (Guenée) (Lepidoptera: Crambidae) on artificial diet. Entomon 41:105-114

Singh SP, Nath P (2010) Cultural and biophysical management of brinjal shoot and fruit borer (Leucinodes orbonalis). A Biannual New letter of the (CIPS) in corporation with the (IRAC) and (WRCC-60) 20(1):42-43

Srinivasan R (2009) Insect and mite pests on eggplant: a field guide for identification and management. AVRDC publication No. 09-729. 64p, Taiwan

Subrahmanyan P, Reddy MN, Rao AS (1983) Exudation of certain organic compounds from seeds of groundnut. Seed Sci Technol 11:267-272
Zhang N, Wu K, He X, Li SQ, Zhang ZH, Shen B, Shen QR (2011) A new bioorganic $n$ fertilizer can effectively control banana wilt by strong colonization with Bacillus subtilis N11. Plant Soil 344:87-97

\section{Publisher's Note}

Springer Nature remains neutral with regard to jurisdictional claims in published maps and institutional affiliations.

\section{Submit your manuscript to a SpringerOpen ${ }^{\circ}$ journal and benefit from:}

- Convenient online submission

- Rigorous peer review

- Open access: articles freely available online

- High visibility within the field

Retaining the copyright to your article

Submit your next manuscript at $\boldsymbol{\nabla}$ springeropen.com 